\title{
Effects of Melatonin and Its Analogues on Pancreatic Inflammation, Enzyme Secretion, and Tumorigenesis
}

\author{
Jolanta Jaworek ${ }^{1}$, Anna Leja-Szpak ${ }^{1}$, Katarzyna Nawrot-Porąbka ${ }^{1}$, Joanna Szklarczyk ${ }^{1}$, \\ Michalina Kot ${ }^{1}$, Piotr Pierzchalski ${ }^{1}$, Marta Góralska ${ }^{1}$, Piotr Ceranowicz ${ }^{2, *}$, \\ Zygmunt Warzecha ${ }^{2}$, Artur Dembinski ${ }^{2}$ and Joanna Bonior ${ }^{1}$
}

1 Department of Medical Physiology, Faculty of Health Sciences, Jagiellonian University Medical College, 31-126 Kraków, Poland; jolanta.jaworek@uj.edu.pl (J.J.); a.leja-szpak@uj.edu.pl (A.L.-S.); k.nawrot-porabka@uj.edu.pl (K.N.-P.); joannam.szklarczyk@uj.edu.pl (J.S.); michalina.kot@uj.edu.pl (M.K.); piotr.pierzchalski@uj.edu.pl (P.P.); marta.goralska@uj.edu.pl (M.G.); joanna.bonior@uj.edu.pl (J.B.)

2 Department of Physiology, Faculty of Medicine, Jagiellonian University Medical College, 31-531 Kraków, Poland; zygmunt.warzecha@uj.edu.pl (Z.W.); artur.dembinski@uj.edu.pl (A.D.)

* Correspondence: piotr.ceranowicz@uj.edu.pl; Tel.: +48-12-421-10-06

Academic Editor: Russel J. Reiter

Received: 30 March 2017; Accepted: 2 May 2017; Published: 8 May 2017

\begin{abstract}
Melatonin is an indoleamine produced from the amino acid L-tryptophan, whereas metabolites of melatonin are known as kynuramines. One of the best-known kynuramines is $N^{1}$-acetyl- $N^{1}$-formyl-5-methoxykynuramine (AFMK). Melatonin has attracted scientific attention as a potent antioxidant and protector of tissue against oxidative stress. L-Tryptophan and kynuramines share common beneficial features with melatonin. Melatonin was originally discovered as a pineal product, has been detected in the gastrointestinal tract, and its receptors have been identified in the pancreas. The role of melatonin in the pancreatic gland is not explained, however several arguments support the opinion that melatonin is probably implicated in the physiology and pathophysiology of the pancreas. (1) Melatonin stimulates pancreatic enzyme secretion through the activation of entero-pancreatic reflex and cholecystokinin (CCK) release. L-Tryptophan and AFMK are less effective than melatonin in the stimulation of pancreatic exocrine function; (2) Melatonin is a successful pancreatic protector, which prevents the pancreas from developing of acute pancreatitis and reduces pancreatic damage. This effect is related to its direct and indirect antioxidant action, to the strengthening of immune defense, and to the modulation of apoptosis. Like melatonin, its precursor and AFMK are able to mimic its protective effect, and it is commonly accepted that all these substances create an antioxidant cascade to intensify the pancreatic protection and acinar cells viability; (3) In pancreatic cancer cells, melatonin and AFMK activated a signal transduction pathway for apoptosis and stimulated heat shock proteins. The role of melatonin and AFMK in pancreatic tumorigenesis remains to be elucidated.
\end{abstract}

Keywords: melatonin; AFMK; enzyme secretion; acute pancreatitis; pancreatic cancer

\section{Melatonin, Its Precursor and Derivatives}

Melatonin ( $N$-acetyl-5-methoxytryptamine) is the main product of the pineal gland, and remains an intriguing substance. Its physiological role is still unclear. This indoleamine is widely distributed among living organisms and has been detected in all living species, from bacteria and plants to mammals [1,2].

Melatonin is able to influence several functions of the organism, including regulation of circadian rhythms, modulation of immune response and hormones release, and reduction of the radical burden of tissues [3-6]. This substance is known as an extremely potent protector of tissues that 
effectively combats oxidative stress and saves the organism from damage induced by toxic radicals $[6,7]$. Tissue protection afforded by melatonin is related to its double antioxidant actions, including: (1) Direct neutralization of devastative reactive oxygen and nitrogen species (ROS and RNS); and (2) Indirect effect through the activation of antioxidant enzymes-superoxide dismutase (SOD), catalase (CAT), glutathione peroxidase (GPx), or glutathione reductase (GR) [7-10]. In addition, melatonin modulates the inflammatory defense of the organism, decreasing the production of pro-inflammatory cytokines such as interleukin $1 \beta$ (IL-1 $\beta$ ), interleukin 6 (IL-6), interleukin 22 (IL-22), tumor necrosis factor $\alpha$ (TNF $\alpha$ ) and increasing the anti-inflammatory interleukin 10 (IL-10) [11-16]. Melatonin is able to control the above-mentioned processes at the cellular level via inhibition of NF- $\mathrm{kB}$, a nuclear transcription factor responsible for the control of genes involved in cell apoptosis and the production of inflammatory mediators, whereas the activation of antioxidant enzymes by melatonin is possibly related to the stimulation of protein kinase $\mathrm{C}(\mathrm{PKC})$ and $\mathrm{Ca}^{2+}$ influx via the induction and nuclear translocation of nuclear transcription factor Nrf1 [12,13,17].

The biological effects of melatonin are mediated by specific membrane receptors $\mathrm{MT}_{1}, \mathrm{MT}_{2} / \mathrm{MT}_{3}$ and probably by its nuclear orphan receptors: retinoid-related orphan receptors and retinoid $\mathrm{Z}$ receptors (ROR/RZR) [18-20]. Transmembrane G-protein-coupled receptors $\mathrm{MT}_{1}$ and $\mathrm{MT}_{2}$ share $60 \%$ homology and could be antagonized by luzindole [21]. Melatonin receptor $\mathrm{MT}_{3}$ has been identified as an enzyme quinone reductase 2 (QR2) and it may be partially responsible for the antioxidant effects of melatonin, whereas the role of nuclear orphan receptors ROR/RZR is unknown [18,19]. Besides its receptor-mediated action, melatonin is capable of free penetration of the cellular membrane barrier, because it is highly lipophilic and this property enables melatonin to effectively protect the cell compartment against oxidative damage [22,23].

Melatonin is produced from the amino acid L-tryptophan, which is converted to serotonin and subsequently to melatonin in processes involving the enzymes arylalkylamino- $N$-acetylserotonin-transferase (AA-NAT) and hydroxyindolo-O-methyl-transferase (HIOMT) [18,24,25]. The gene expression of both enzymes has been identified in the gut and in the pancreas [18,24-27]. L-tryptophan has been shown to protect the tissues in a way similar to its derivative, melatonin [26].

Melatonin can be metabolized in several ways, involving deacetylation, cytochrome P450s-mediated processes, and classic kynurenic pathway, with key enzyme indoleamine 2,3-dioxygenase (IDO) [28,29]. The metabolic products of melatonin and of L-tryptophan are known as kynuramines. Among them, the best-known melatonin derivatives are $N^{1}$-acetyl- $N^{1}$-formyl-5-methoxykynuramine (AFMK), and $N^{1}$-acetyl-5-methoxy-kynuramine (AMK). These molecules can be generated from melatonin by myeloor hemoperoxidase enzymes, and also by free radicals or by ultraviolet radiation [30]. Like its maternal molecule, AFMK has been demonstrated as an effective cell protector against oxidative stress. It is able to neutralize reactive molecules (mainly hydroxyl $(\bullet \mathrm{OH})$ radical) and can reduce membrane lipid peroxidation and DNA damage; however, its scavenging effect is weaker than the antioxidant properties of melatonin [31-35]. AFMK has been found in many organisms (including mammals, where it was identified in the eye, in the brain, and in the skin); however, this melatonin derivative was not detected in the serum under normal conditions [30-32]. It has been suggested that an increased formation of AFMK from melatonin could be indicative of activation of inflammatory processes, and indeed AFMK was identified in the cerebrospinal fluid of patients with meningitis $[29,36]$. AFMK was markedly increased in the human epidermal keratinocytes exposed to UVB radiation, which is consistent with the photoprotective role of melatonin and its metabolites [32].

\section{Melatonin and Its Receptors in the Pancreas}

Melatonin — previously identified as an exceptional pineal product—can be synthetized in many other tissues, such as retina, brain, heart, blood vessels, immune cells, and the gastrointestinal system $[18,34,37-40]$. The main source of melatonin is probably the gastrointestinal tract, with the estimated amount of produced melatonin ranging 400 times higher than that in the pineal gland $[37,39,40]$. 
It is of interest that the pancreas is probably also able to synthetize melatonin, as was evidenced by the presence of mRNA signals for AA-NAT and HIOMT in the rat pancreatic acini and in human pancreatic tissue $[26,27,40]$. Melatonin concentration in the pancreatic tissue undergoes circadian fluctuation and mimics the characteristic changes of melatonin in the pineal gland, with a higher amount during the dark phase and lower during the day (10 and $5 \mathrm{pg} / 100 \mathrm{mg}$ of tissue, respectively) [20]. These changes are independent of the pineal gland, but can be associated with ingested food [41].

Melatonin receptors have been identified in the pancreatic islets of Langerhans (in $\beta$-cells and in $\alpha$-cells), in the azaserine-induced malignant nodules from the rat pancreas (pancreatic acinar cell line) AR42J, and in the human pancreatic cancer cell line PANC-1 [42-44].

\section{Role of Melatonin and Its Analogues in Pancreatic Enzyme Secretion}

Previous experimental studies have demonstrated that melatonin and its precursor L-tryptophan given parenterally or into the duodenal lumen produced significant increases of pancreatic enzymes secretion $[27,45,46]$. Since both key enzymes involved in the transformation of L-tryptophan into melatonin were detected in the cells of gut mucosa and the application of L-tryptophan resulted in a dose-dependent rise of melatonin blood level, it could be presumed that L-tryptophan itself is not responsible for the stimulation of the pancreatic enzymes, but melatonin derived from its precursor in the gut lumen.

Melatonin appears as a very potent pancreatic secretagogue. A $25 \mathrm{mg} / \mathrm{kg}$ dose of melatonin given intraduodenally produced enzyme secretion similar to the level achieved by the administration of $1 \mu \mathrm{g} / \mathrm{kg}$ of cholecystokinin (CCK) (near maximal secretion) [45]. The pancreatostimulatory effect of melatonin was much stronger with intraluminal administration of this ingredient when compared to the increased pancreatic enzyme secretion evoked by its application into the blood stream [45]. This observation indicates that the stimulatory effect of melatonin and related substances is dependent on the activation of receptors located in the intestine rather than in the pancreatic gland. This suggestion was supported by the observation that melatonin failed to produce the secretory response from isolated rat pancreatic acini. A controversial observation was published by Santofimia-Castaño, P. et al. [47], who demonstrated that melatonin reduced calcium mobilization and attenuated amylase release stimulated by CCK in mouse pancreatic acini. The differences between our results and the observation of Santofimia-Castaño, P. may be explained by variances between species used in the in vitro experiments, or perhaps by a competitive inhibitory effect of melatonin and CCK on calcium mobilization and enzyme secretion.

The mechanism of the stimulatory action of melatonin on pancreatic exocrine function appears indirect and in need of the release of CCK, because application of melatonin or its precursor resulted in dose-dependent increase of CCK blood level. In addition, melatonin-evoked pancreatic secretory response was completely blocked by CCK receptor antagonists such as tarazepide or L-364,718, as well as by deactivation of sensory nerves by capsaicin. This observation leads to the conclusion that stimulation of pancreatic enzyme secretion evoked by intraluminal melatonin is dependent on the release of CCK and activation (directly or indirectly, via CCK) of the duodeno-pancreatic reflex [46].

Melatonin is present in the gut lumen as a component of ingested food, or as derivative of L-tryptophan and serotonin [48,49]. It is very likely that melatonin could play an essential role in the physiological stimulation of exocrine pancreatic function. Melatonin possibly acts as one of the mediators involved in the intestinal phase of pancreatic secretion via the activation of the neural entero-pancreatic reflex. L-tryptophan seems to function as a melatonin precursor, whereas role of AFMK in the regulation of pancreatic exocrine function remains to be clarified.

\section{Melatonin System and Acute Pancreatitis}

Acute pancreatitis is a primary sterile disease of the pancreas, classified as edematous or hemorrhagic-necrotizing form, according to the morphological changes of the pancreatic tissue. 
Edematous pancreatitis has a good prognosis, but the severe hemorrhagic-necrotizing type of pancreatic inflammation is characterized by high mortality rate $[50,51]$. The pathogenesis of acute pancreatitis is not completely explained, and the main mechanism has been based on the concept of pancreas self-digestion, being the consequence of the intracellular activation of pancreatic digestive enzymes (mainly trypsin) leading to acinar cell necrosis [52]. Toxic ingredients released from the damaged structures such as ROS and RNS, products of arachidonic acid metabolism (prostaglandins, leukotrienes, thromboxanes), and other noxious agents work as propagators of sterile inflammation and chemoattractants for inflammatory cells, leading to the increased production of pro-inflammatory cytokines (e.g., TNF $\alpha$, IL-6, IL-8). This is accompanied by vascular endothelium damage, increased vascular permeability, and processes of intensified coagulation and fibrinolysis [52-55]. Local pancreatic inflammation could develop into systemic inflammatory response (SIRS), often leading to multiple organ dysfunction (MODS) and septic shock [55,56].

The activation of proinflammatory mechanisms in acute pancreatitis is followed by the mobilization of the compensatory anti-inflammatory response syndrome of the organism (CARS), which could limit or suppress the process of inflammation. The prevalence of pro-inflammatory agents leads to the propagation of acute pancreatitis, whereas stimulation of natural defense mechanisms results in the suppression of inflammatory process [57,58].

Melatonin has been recognized as one of the elements of the innate defense system and a very effective pancreatic protector [2,59]. Previous experimental studies have shown that pretreatment with melatonin could prevent pancreatic inflammation and radically reduce pancreatic tissue damage in rats subjected to acute pancreatitis in different experimental models [13,59-73]. This was evidenced by histological assessment of pancreatic tissue and prominent decline of the inflammatory markers, such as edema, neutrophil infiltration, and vacuolization of the acinar cells [60-63,73]. In animals with acute pancreatitis pretreated with melatonin, there was a significant reduction in the plasma morphometric indicators of pancreatic inflammation severity, blood levels of the enzymes, amylase and lipase, and blood levels of pro-inflammatory cytokines (e.g., TNF $\alpha$, IL-1 $\beta$, and IL-6), whereas anti-inflammatory interleukins IL-10 and IL-4 were increased $[10,59,62-70]$. The antioxidant effect of melatonin was expressed as a reduction of lipid peroxidation products (MDA + 4-HNE) in the pancreas and was accompanied by increased activity of antioxidant enzymes SOD, CAT, GPx, and GSH [62-67,69,70]. Other mechanisms of the protective action of melatonin on acute pancreatitis involve the improvement of pancreatic blood flow, the reduction of prostaglandin generation, a decrease in myeloperoxidase (MPO), the moderation of apoptosis and necrosis processes in the pancreatic tissue, and synthesis of heat shock proteins $[63,66,69,72,74]$. Moreover, melatonin has been shown to protect against lung injury and to save gut barrier integrity to reduce bacterial translocation and to prevent sepsis and MODS in acute pancreatitis [75,76]. Furthermore, the recovery from acute pancreatitis and pancreatic regeneration was improved by melatonin [77].

This potent favorable effect of melatonin on acute pancreatitis is not related to an individual action of melatonin, but perhaps depends on the involvement of a whole melatonin system with the contribution of the melatonin precursor L-tryptophan as well as the participation of melatonin derivatives. Our recent study has shown that one of them-melatonin metabolite AFMK-is also able to attenuate the severity of acute pancreatic inflammation. Administration of AFMK to rats prior to the induction of caerulein-induced pancreatitis significantly reduced pancreatic tissue damage in a way similar to its maternal molecule, melatonin. AFMK reduced the morphometric signs of inflammation, decreased amylase serum activity and TNF $\alpha$ serum concentration, and increased the antioxidant potency of pancreatic tissue, which was evidenced by the rise of the antioxidant enzyme GPx in the pancreas, accompanied by the significant decline of pancreatic lipid peroxidation products MDA + 4-HNE [78].

Looking for the protective mechanisms of melatonin and AFMK at the molecular level, we have observed that both substances stimulated the protein expression of GPx, while reducing that of TNF $\alpha$ in the acinar pancreatic cell line AR42J subjected to high doses of caerulein. In addition, AFMK and its 
maternal molecule modulated the apoptotic signal transduction pathway in these cells, leading to the activation of the proapoptotic enzyme caspase-3 [78]. Apoptosis (programmed cell death) prevents cell membranes from interruption and appears as a process limiting the inflammatory reactions in the tissues; this is unlike necrosis, which destroys tissue by rupturing cellular membranes and releases lysosomal enzymes and inflammatory mediators outside of the cell, facilitating the propagation of inflammation $[79,80]$. Melatonin has previously been demonstrated to improve signals for proapoptotic enzymes caspase-3 and caspase-7 in cancer cells [81-83]. In the pancreatic cell line, both melatonin and AFMK enhanced proapoptotic Bax protein and reduced signals for antiapoptotic Bcl-2, and this was followed by the rise of active caspase-3, executor of apoptosis [82].

Another protective mechanism of melatonin and AFMK in the pancreas could be related to the suppression of inducible nitric oxide synthase (iNOS) activity. This isoenzyme is responsible for excessive generation of nitric oxide (NO) and the formation of toxic RNS in acute pancreatitis [13]. Melatonin has been demonstrated to diminish the expression of iNOS in the pancreas of rats subjected to acute pancreatitis. Like its precursor molecule, AFMK also prevented activation of iNOS with subsequent reduction of $\mathrm{NO}$ concentration in activated macrophages [34]. This effect could possibly be involved in the alleviation of inflammatory processes afforded by the melatonin system in the pancreas.

Results of experimental studies presented evidence that melatonin may take part in the natural defense system improving pancreatic resistance against inflammation, and that the elimination of endogenous melatonin by the application of an antagonist of melatonin $\mathrm{MT}_{1} / \mathrm{MT}_{2}$ receptors (luzindole) worsened the course of acute pancreatitis and increased lipid peroxidation in the inflamed pancreas [63]. Another argument supporting the role of endogenous melatonin in the innate pancreatic defense came from the observation that in pinealectomized rats subjected to acute pancreatitis, the inflammatory changes of the gland were significantly aggravated compared to animals with intact pineal gland subjected to pancreatic inflammation [84].

The possible implication of melatonin in the innate defense of the pancreas against acute inflammation was supported by clinical observations, showing that in patients with acute pancreatitis, high melatonin blood concentration observed in the first $24 \mathrm{~h}$ after the onset of pancreatic inflammation was correlated with a mild course and optimistic prognosis for patients, whereas severe pancreatitis was accompanied with low melatonin blood level $[85,86]$.

All above results of experimental studies together with clinical observations supported the notion of the important role of the melatonin system in the innate defense protecting the pancreatic gland from inflammatory damage. The prolonged and effective pancreatic protection results from the common beneficial action of melatonin, its precursor, and its metabolites. All these substances create an antioxidant cascade, and work together to increase antioxidant resistance of pancreatic tissue and to protect acinar cells viability.

\section{Melatonin System and Pancreatic Cancer}

The results of our previous study provided the evidence that melatonin given to the pancreatic cancer cells PANC-1 activated the pro-apoptotic signal transduction pathway and stimulated the expression of caspase-9, thus activating the mitochondrial pathway of apoptosis. However, the activation of executor of apoptosis (caspase-3) and DNA fragmentation have not been observed, indicating that the apoptotic process might not be completed $[43,87,88]$. The pro-apoptotic effect of melatonin on pancreatic tumor cells has been demonstrated by Li et al. and $\mathrm{Xu}$ et al., who have shown that the application of melatonin to cancer cells resulted in the strong expression of pro-apoptotic Bax proteins followed by the activation of caspase- 3 and inhibition of an anti-apoptotic protein Bcl-2 [82,89]. Similar results have been demonstrated in the pancreatic AR42J tumor acinar cells. Melatonin reduced the viability of these cells via the activation of caspase- 3 and modulation of mitochondrial activity [44]. Moreover, melatonin has been demonstrated to up-regulate $\mathrm{Bax} / \mathrm{Bcl}-2$ or $\mathrm{Bax} / \mathrm{Bcl}-\mathrm{xL}$ proteins ratio followed by activation of caspase- 9 and caspase- 7 in the cultures of breast, lung, and colon cancer cells [90-92]. 
The effects of melatonin on pancreatic cancer cells could be related to the activation of melatonin membrane receptors $\left(\mathrm{MT}_{1} / \mathrm{MT}_{2}\right)$, because pretreatment with luzindole (antagonist of these receptors) reversed the stimulatory effect of melatonin on $\mathrm{Bcl}-2 / \mathrm{Bax}$ balance and caspase- 9 proteins expression in PANC-1 cells [43].

To the best of our knowledge, only a few observations concerning the effects of melatonin metabolite AFMK on pancreatic tumor cells have been published to date. A single study of Kim et al. demonstrated that melatonin derivatives such as 6-hydroxymelatonin, AFMK, and 5-methoxytryptamine inhibited the proliferation of human normal epidermal melanocytes and melanoma cells [93]. Our recent publication showed that AFMK given to human pancreatic carcinoma cells (PANC-1) increased the signal for the anti-apoptotic heat shock proteins nuclear p-HSP27, cytoplasmic HSP90 $\alpha / \beta$, and HSP70. These effects could be related to the activation of melatonin membrane receptors by AFMK, because luzindole (antagonist of these receptors) reversed AFMK-induced stimulation of HSPs in PANC-1 cells [94]. The observation concerning the involvement of $\mathrm{MT}_{1} / \mathrm{MT}_{2}$ receptor in the effect of $\mathrm{AFMK}$ is in agreement with previous reports, showing that AFMK is able to bind to the melatonin membrane receptor, but its affinity to this receptor is lower than that of melatonin [34,95-99].

According to the data of $\mathrm{Li}$ et al. [89], melatonin inhibited cell viability, suppressed colony formation, reduced cell migration and invasion, and induced cell apoptosis in pancreatic carcinoma cells. In addition, recent studies have shown that high doses $(\mathrm{mM})$ of melatonin decreased pancreatic tumor cells proliferation and invasion by inhibition of NF- $\mathrm{KB}$ signaling pathway, but also enhanced gemcitabine cytotoxicity in these cells [100]. A supporting action of melatonin in antitumor therapy has also been demonstrated by Uguz et al. [101], who observed that melatonin enhances the antiproliferative effects of cytostatics such as 5 -fluorouracil or cisplatin on pancreatic rat carcinoma. Co-treatment of cancer cells with these therapeutic agents in the presence of melatonin increased the population of apoptotic cells, and this effect was related to the increased production of reactive oxygen species [101]. Our recent unpublished results have also shown that combined treatment of PANC-1 cells with gemcitabine together with melatonin or its metabolite AFMK increased the therapeutic effects of gemcitabine. The results of our experiments together with the above-cited publications could suggest the possible future management of patients with pancreatic cancer with gemcitabine plus melatonin or its metabolite. Based on in vitro results, this combination could possibly give better perspectives for these patients, but future studies are required.

\section{Conclusions}

The melatonin system, including melatonin precursor L-tryptophan and the melatonin derivatives kynuramines, is probably implicated in pancreatic physiology and its malfunctioning, resulting in the impairment of pancreatic functions and pancreatic resistance to inflammation and cancer. The role of the melatonin system in the pancreas can be summarized as follows:

1. Melatonin and its related molecules may be involved in the physiological stimulation of pancreatic exocrine secretion dependent on the stimulation of CCK release and activation of duodeno-pancreatic neural reflex (Figure 1).

2. Melatonin might be implicated in the activation of the innate defense system of pancreatic protection, and its derivatives are responsible for a considerable part of the protective action of melatonin on the pancreas as part of its scavenging cascade (Figure 2).

3. Melatonin and its metabolites take part in the control of the increased production of heat shock proteins as well as in the signal transmission pathways modulating the process of apoptosis in pancreatic cancer cells, however its effect is not completely clear and requires further study (Figure 2). 


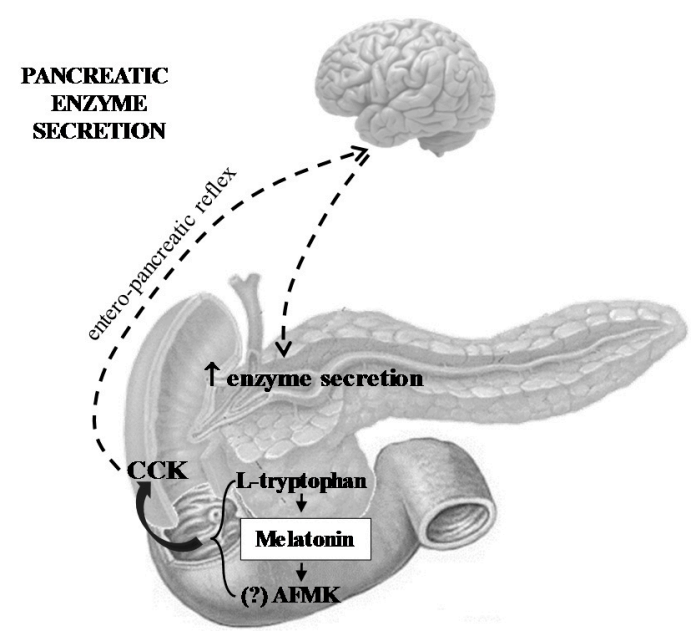

Figure 1. The effect of melatonin, its precursor L-tryptophan, and melatonin metabolite AFMK on pancreatic enzyme secretion. AFMK: $N^{1}$-acetyl- $N^{1}$-formyl-5-metoxykynuramine, CCK: cholecystokinin, dotted line arrow: nervous signal transmission via vago-vagal, entero-pancreatic reflex, up arrow: nervous signal delivery, bold arrow: CCK release stimulated by L-tryptophan, melatonin, and probably (?) by AFMK.

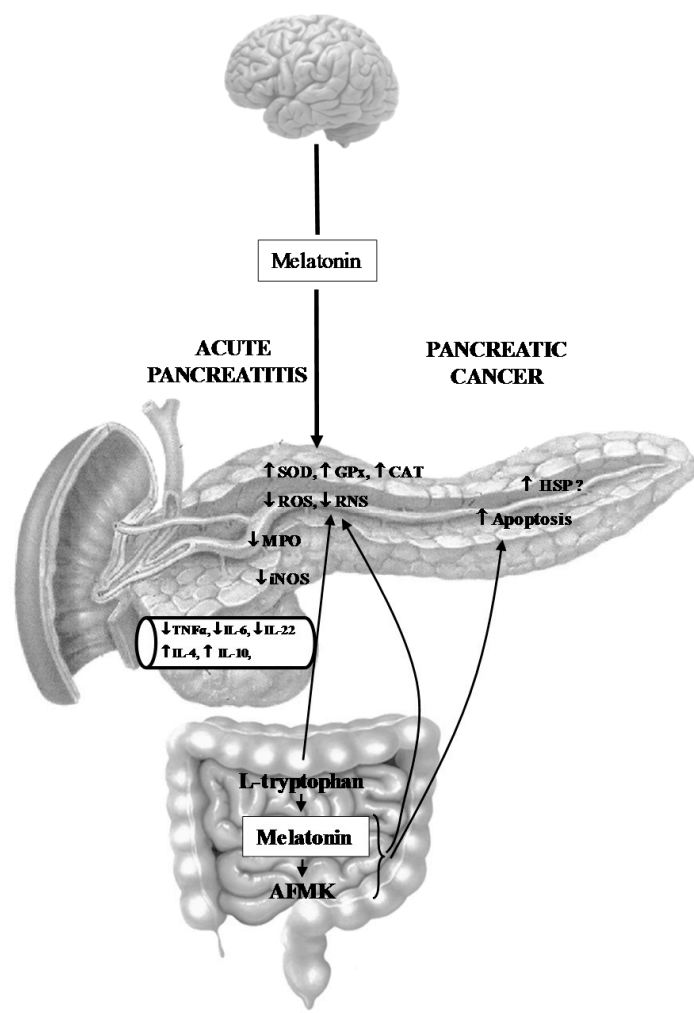

Figure 2. Effect of melatonin and its analogues on acute pancreatitis and on pancreatic tumorigenesis. CAT: catalase; GPx: glutathione peroxidase; HSP: heat shock protein; IL: interleukin; iNOS: inducible nitric oxide synthase; MPO: myeloperoxidase; ROS and RNS: reactive oxygen and nitrogen species; SOD: superoxide dismutase; TNF $\alpha$ : tumor necrosis factor $\alpha$, AFMK: $N^{1}$-acetyl- $N^{1}$-formyl-5-metoxykynuramine, up arrow: effect of melatonin and its analogues on inflammatory mediators in acute pancreatitis and on molecular mechanism of pancreatic tumorigenesis, ?: possible activation of HSP by melatonin and AFMK, down arrow: pineal melatonin alleviated acute pancreatitis. 
Acknowledgments: The studies were supported by projects nr K/ZDS/00366 and nr K/ZDS/005477. Costs of publication were paid by the Leading National Research Center in Krakow (KNOW).

Author Contributions: Jolanta Jaworek conceived, designed, analyzed the data and wrote parts 1-4, 6 of paper; Anna Leja-Szpak wrote part 5 of paper, Katarzyna Nawrot-Porabka, Joanna Szklarczyk, Michalina Kot, Piotr Pierzchalski, Marta Góralska, Piotr Ceranowicz, Zygmunt Warzecha, Artur Dembinski and Joanna Bonior performed the literature search, analyzed the data and contributed to writing the paper.

Conflicts of Interest: The authors declare no conflict of interest.

\section{References}

1. Reiter, R.J.; Tan, D.X.; Rosales-Corral, S.; Manchester, L.C. The universal nature, unequal distribution and antioxidant functions of melatonin and its derivatives. Mini Rev. Med. Chem. 2013, 13, 373-384. [CrossRef] [PubMed]

2. Calvo, J.R.; Gonzales-Yanes, C.; Maldonado, M.D. The role of melatonin in the cells of the innate immunity: A review. J. Pineal Res. 2013, 55, 103-120. [CrossRef] [PubMed]

3. Zawilska, J.B.; Skene, D.J.; Arendt, J. Physiology and pharmacology of melatonin in relation to biological rhythms. Pharmacol. Rep. 2009, 61, 383-410. [CrossRef]

4. Ren, W.; Liu, G.; Chen, S.; Yin, J.; Wang, J.; Tan, B.; Wu, G.; Bazer, F.W.; Peng, Y.; Li, T.; et al. Melatonin signaling in T cells: Functions and applications. J. Pineal Res. 2017, 62. [CrossRef] [PubMed]

5. Mańka, S.; Majewska, E. Immunoregulatory action of melatonin. The mechanism of action and the effect on inflammatory cells. Postepy Hig. Med. Dosw. 2016, 70, 1059-1067. [CrossRef]

6. Chojnacki, C.; Wisniewska-Jarosińska, M.; Walecka-Kapica, E.; Klupińska, G.; Jaworek, J.; Chojnacki, J. Evaluation of melatonin effectiveness in the adjuvant treatment of ulcerative colitis. J. Physiol. Pharmacol. 2011, 62, 327-334. [PubMed]

7. Reiter, R.J.; Mayo, J.C.; Tan, D.X.; Sainz, R.M.; Alatorre-Jimenez, M.; Oin, L. Melatonin as an antioxidant: Under promises but over delivers. J. Pineal Res. 2016, 61, 253-278. [CrossRef] [PubMed]

8. Goc, Z.; Szaroma, W.; Kapusta, E.; Dziubek, K. Protective effects of melatonin on the activity of SOD, CAT, GSH-Px and GSH content in organs of mice after administration of SNP. Chin. J. Physiol. 2017, 60, 1-10. [CrossRef] [PubMed]

9. Miller, E.; Mrowicka, M.; Malinowska, K.; Kędziora, J.; Majsterek, I. The effect of whole body cryotherapy and melatonin supplementation on total antioxidative status and some antioxidative enzyme in multiple sclerosis patients. Pol. Merkur. Lek. 2011, 31, 150-153.

10. Colares, J.R.; Schemitt, E.G.; Hartmann, R.M.; Licks, F.; Soares, M.D.; Bosco, A.D.; Marroni, N.P. Antioxidant and anti-inflammatory action of melatonin in an experimental model of secondary biliary cirrosis induced by bile duct ligation. World J. Gastroenterol. 2016, 22, 8918-8928. [CrossRef] [PubMed]

11. Cutando, A.; Montero, J.; Gomez-de Diego, R.; Ferrera, M.J.; Lopez-Valverde, A. Effect of topical melatonin on serum levels of C-rective protein (CRP), interleukin-6 (IL-6), and tumor necrosis factor- $\alpha$ (TNF $\alpha$ ) in patients with type 1 or type 2 diabetes and periodontal disease. J. Clin. Exp. Dent. 2015, 7, e628-e633. [PubMed]

12. Maldonado, M.D.; Garcia-Moreno, H.; Gonzales-Yanes, C.; Calvo, J.R. Possible involvement of the inhibition of NF- $\mathrm{KB}$ factor in anti-inflammatory actions that melatonin exerts on mast cells. J. Cell. Biochem. 2016, 117, 1926-1933. [CrossRef] [PubMed]

13. Jung, K.H.; Hong, S.W.; Zheng, H.M.; Lee, H.S.; Lee, H.; Lee, D.H.; Lee, S.Y.; Hong, S.S. Melatonin ameliorates caerulein-induced pancreatitis by the modulation of nuclear erythroid 2-related factor 2 and nuclear factor-kappa B in rats. J. Pineal Res. 2010, 48, 239-250. [CrossRef] [PubMed]

14. Chen, S.J.; Huangh, S.H.; Chen, J.W.; Wang, K.C.; Yang, Y.R.; Liu, P.F.; Lin, G.J.; Sytwu, H.K. Melatonin enhances interleukin-10 expression and suppresses chemotaxis to inhibit inflammation in situ and reduce the severity of experimental autoimmune encephalomyelitis. Int. Immunopharmacol. 2016, 32, 169-177. [CrossRef] [PubMed]

15. Huai, J.P.; Sun, X.C.; Chen, M.J.; Jin, Y.; Ye, X.H.; Wu, J.S.; Huang, Z.M. Melatonin attenuates acute pancreatitis-associated lung injury inn rats by modulating interleukin 22. World J. Gastroenterol. 2012, 18, 5122-5128. [CrossRef] [PubMed] 
16. Ochoa, J.J.; Diaz-Castro, J.; Kajarabille, N.; Garcia, N.; Guisado, I.M.; De Teresa, C.; Guisado, R. Melatonin supplementation ameliorates oxidative stress and inflammatory signaling induced by strenuous exercise in adult human males. J. Pineal Res. 2011, 51, 373-380. [CrossRef] [PubMed]

17. Santofimia-Castano, P.; Clea Ruy, D.; Garcia-Sanchez, L.; Jimenez-Blasco, D.; Fernandez-Bermejo, M.; Bolanos, J.P.; Salido, G.M.; Gonzales, A. Melatonin induces the expression of Nrf2-regulated antioxidant enzymes via PKC and $\mathrm{Ca}^{2+}$ influx activation in mouse pancreatic acinar cells. Free Radic. Biol. Med. 2015, 87, 226-236. [CrossRef] [PubMed]

18. Chen, C.Q.; Fichna, J.; Bashashati, M.; Li, Y.Y.; Storr, M. Distribution, function and physiological role of melatonin in the lower gut. World J. Gastroenterol. 2011, 17, 3888-3898. [CrossRef] [PubMed]

19. Slominski, R.M.; Reiter, R.J.; Schlabritz-Loutsevitch, N.; Ostrom, R.S.; Slominski, A.T. Melatonin membrane receptors in peripheral tissues: Distribution and functions. Mol. Cell. Endocrinol. 2012, 35, 152-166. [CrossRef] [PubMed]

20. Stebelova, K.; Anttila, K.; Manttari, S.; Saarela, S.I.; Zeman, M. Immunohistochemical definition of MT(2) receptors and melatonin in the gastrointestinal tissues of rat. Acta Histochem. 2010, 112, 26-33. [CrossRef] [PubMed]

21. Ahmed, R.; Mahavadi, S.; Al-Shboul, O.; Bhattacharya, S.; Grider, J.R.; Muthry, K.S. Characterization of signaling pathways coupled to melatonin receptors in gastrointestinal smooth muscle. Regul. Pept. 2013, 184, 96-103. [CrossRef] [PubMed]

22. Costa, E.J.; Lopes, R.H.; Lamy-Freund, M.T. Permeability of pure lipid bilayers to melatonin. J. Pineal Res. 1995, 19, 123-126. [CrossRef] [PubMed]

23. Reiter, R.J.; Tan, D.X.; Manchester, L.C.; Pilar-Terron, M.; Flores, L.J.; Koppisepi, S. Medical implications of melatonin: Receptor-mediated and receptor-independent actions. Adv. Med. Sci. 2007, 52, 11-28. [PubMed]

24. Stefulj, J.; Hortner, M.; Ghosh, M.; Schauenstein, K.; Rinner, I.; Wolfler, A.; Sonner, J.; Liebman, P.M. Gene expression of the key enzymes in melatonin synthesis in extrapineal tissues in the rat. J. Pineal Res. 2001, 30, 243-247. [CrossRef] [PubMed]

25. Shimozuma, M.; Tokuyama, R.; Tatehara, S.; Umeki, H.; Ide, S.; Mishima, K.; Saito, I.; Satomura, K. Expression and cellular localization of melatonin-synthesis enzyme in rat and human salivary glands. Histochem. Cell Biol. 2011, 135, 389-396. [CrossRef] [PubMed]

26. Jaworek, J.; Leja-Szpak, A.; Bonior, J.; Nawrot, K.; Tomaszewska, R.; Stachura, J.; Sendur, R.; Konturek, S.J. Protective effect of melatonin and its precursor L-tryptophan on acute pancreatitis induced by caerulein overstimulation or ischemia/reperfusion. J. Pineal Res. 2003, 34, 40-52. [CrossRef] [PubMed]

27. Jaworek, J.; Nawrot-Porabka, K.; Leja-Szpak, A.; Bonior, J.; Szklarczyk, J.; Kot, M.; Konturek, S.J.; Pawlik, W.W. Melatonin as modulator of pancreatic enzyme secretion and pancreatoprotector. J. Physiol. Pharmacol. 2007, 58, 65-80. [PubMed]

28. Ciorba, M.A. Indoleamine 2,3 dioxygenase in intestinal disease. Curr. Opin. Gastroenterol. 2013, $29,146-152$. [CrossRef] [PubMed]

29. Tan, D.X.; Manchester, L.C.; Terron, M.P.; Flores, L.J.; Reiter, R.J. One molecule, many derivatives: A never-ending interaction of melatonin with the reactive oxygen and nitrogen species. J. Pineal Res. 2007, 42, 28-42. [CrossRef] [PubMed]

30. Harderland, R.; Tan, D.X.; Reiter, R.J. Kynuramines, metabolites of melatonin and other indoles: The resurrection of an almost forgotten class of biogenic amines. J. Pineal Res. 2009, 42, 109-126. [CrossRef] [PubMed]

31. Tan, D.X.; Manchester, L.C.; Burkhardt, S.; Sainz, R.M.; Mayo, J.C.; Kohen, R.; Shohami, E.; Huo, Y.S.; Hardeland, R.; Reiter, R.J. $N^{1}$-acetyl- $N^{1}$-formyl-5-methoxy-kynuramine, a biogenic amine and melatonin metabolite, functions as a potent antioxidant. FASEB J. 2001, 15, 2294-2296. [PubMed]

32. Janjetovic, Z.; Nahmias, Z.P.; Hanna, S.; Jarrett, S.G.; Kim, T.K.; Reiter, R.J.; Slominski, A.T. Melatonin and its metabolites ameliorate ultraviolet B-induced damage in human epidermal keratinocytes. J. Pineal Res. 2014, 57, 90-102. [CrossRef] [PubMed]

33. Schaefer, M.; Hardeland, R. The melatonin metabolite $N^{1}$-acetyl- $N^{1}$-formyl-5-methoxy- kynuramine is a potent singlet oxygen scavenger. J. Pineal Res. 2009, 46, 49-52. [CrossRef] [PubMed] 
34. Mayo, J.C.; Sainz, R.M.; Tan, D.X.; Hardeland, R.; Leon, J.; Rodriguez, C.; Reiter, R.J. Antinflammatory action of melatonin and its metabolites $N^{1}$-acetyl- $N^{1}$-formyl-5-methoxykynuramine (AFMK), and N1-acetyl-5-methoxykynuramine (AMK) in macrophages. J. Neuroimmunol. 2005, 165, 139-149. [CrossRef] [PubMed]

35. Galano, A.; Tan, X.; Reiter, R.J. On the free radical scavenging activities of melatonin's metabolites, AFMK and AMK. J. Pineal Res. 2013, 54, 245-257. [CrossRef] [PubMed]

36. Silva, S.O.; Ximenez, V.F.; Livramento, J.A.; Catalani, L.H.; Campa, A. High concentration of melatonin metabolite $N^{1}$-acety- $N^{1}$ formyl-5-methoxykynuramine in cerebrospinal fluid of patients with meningitis; a possible immunomodulatory mechanism. J. Pineal Res. 2005, 39, 302-306. [CrossRef] [PubMed]

37. Acuna-Castroviejo, D.; Escames, G.; Vernegas, C.; Diaz-Casado, M.E.; Lima-Cabello, E.; Lopez, L.C.; Rosales-Corral, S.; Tan, D.X.; Reiter, R.J. Extrapineal melatonin: Sources, regulation and potential functions. Cell Mol. Life Sci. 2014, 71, 2997-3025. [CrossRef] [PubMed]

38. Hardeland, R.; Poeggeler, B. Melatonin and synthetic melatonergic agonists: Actions and metabolism in the central nervous system. Cent. Nerv. Syst. Agents Med. Chem. 2012, 12, 189-216. [CrossRef] [PubMed]

39. Bubenik, G.A. Localization, physiological significance and possible clinical implication of gastrointestinal melatonin. Biol. Signals Recept. 2001, 10, 350-366. [CrossRef] [PubMed]

40. Soderquist, F.; Hellstrom, P.M.; Cunningham, J.L. Human gastroenteropancreatic expression of melatonin and its receptors MT1 and MT2. PLoS ONE 2015, 10, e0120195. [CrossRef] [PubMed]

41. Bubenik, G.A.; Brown, G.M. Pinealectomy reduces melatonin levels in the serum but not in the gastrointestinal tract of the rat. Biol. Signals 1997, 6, 40-44. [CrossRef] [PubMed]

42. Peschke, E.; Bahr, I.; Muhlbauer, E. Melatonin and pancreatic islets: Interrelationships between melatonin, insulin and glucagon. Int. J. Mol. Sci. 2013, 14, 6981-7015. [CrossRef] [PubMed]

43. Leja-Szpak, A.; Jaworek, J.; Pierzchalski, P.; Reiter, R.J. Melatonin Induces Pro-apoptotic Signaling Pathway in Human Pancreatic Carcinoma Cells (PANC-1). J. Pineal Res. 2010, 49, 248-255. [CrossRef] [PubMed]

44. Gonzales, A.; del Castillo-Vaquero, A.; Miro-Moran, A.; Tapia, J.A.; Salido, G.M. Melatonin reduces pancreatic tumor cell viability by altering mitochondrial physiology. J. Pineal Res. 2011, 50, 250-260. [CrossRef] [PubMed]

45. Jaworek, J.; Nawrot-Porabka, K.; Konturek, S.J.; Leja-Szpak, A.; Thor, P.; Pawlik, W.W. Melatonin and its precursor L-tryptophan: Influence on pancreatic amylase secretion in vivo and in vitro. J. Pineal Res. 2004, 36, 155-164. [CrossRef] [PubMed]

46. Leja-Szpak, A.; Jaworek, J.; Nawrot-Porabka, K.; Palonek, M.; Mitis-Musiol, M.; Dembinski, A.; Konturek, S.J.; Pawlik, W.W. Modulation of pancreatic enzyme secretion by melatonin and its precursor: L-tryptophan. Role of CCK and afferent nerves. J. Physiol. Pharmacol. 2004, 55, 33-46. [PubMed]

47. Santofimia-Castaño, P.; Ruy, D.C.; Salido, G.M.; Gonzales, A. Melatonin modulates $\mathrm{Ca}^{2+}$ mobilization and amylase release in response to cholecystokinin octapeptide in mouse pancreatic acinar cells. J. Physiol. Biochem. 2013, 69, 897-908. [CrossRef] [PubMed]

48. Bernard, P.P.; Polglaze, K.E.; Bernard, R.L.; Sandow, S.L.; Pozo, M.J. Detection of melatonin production from the intestinal epithelium using electochemical method. Curr. Pharm. Des. 2014, 20, 4802-4806.

49. Hardeland, R. Melatonin in plants-diversity of levels and multiplicity of functions. Front. Plant Sci. 2016, 7, 198. [CrossRef] [PubMed]

50. Bharwani, N.; Patel, S.; Prabhudesai, S.; Fotheringham, T.; Power, N. Acute pancreatitis: The role of imagining in diagnosis and management. Clin. Radiol. 2011, 66, 164-175. [CrossRef] [PubMed]

51. Gurusamy, K.S.; Belgaumkatr, A.P.; Haswell, A.; Pereira, S.P.; Davidson, B.R. Interventions for necrotizing pancreatitis. Cochrane Database Syst. Rev. 2016, 4, CD011383. [PubMed]

52. Singh, P.; Garg, P.K. Pathophysiological mechanisms in acute pancreatitis: Current understanding. Indian J. Gastroenterol. 2016, 35, 153-166. [CrossRef] [PubMed]

53. Sah, R.P.; Dawra, R.K.; Saluja, A.K. New insights into the pathogenesis in pancreatitis. Curr. Opin. Gastroenterol. 2013, 29, 523-530. [CrossRef] [PubMed]

54. Manohar, M.; Verma, A.K.; Venkateshaiah, S.U.; Sanders, N.L.; Mishra, A. Pathogenetic mechanism of pancreatitis. World J. Gastrointest. Pharmacol. Ther. 2017, 8, 10-25. [CrossRef] [PubMed] 
55. Mylona, V.; Koussoulas, V.; Tzivras, D.; Makrygiannis, E.; Georgopoulou, P.; Koratzanis, G.; Giamarellos-Bourboulis, E.J.; Tzivras, M.D. Changes in adaptative and innate immunity in patients with acute pancreatitis and systemic inflammatory response syndrome. Pancreatology 2011, 11, 475-481. [CrossRef] [PubMed]

56. Bhatia, M. Acute pancreatitis as a model of SIRS. Front. Biosci. 2009, 14, 2042-2050. [CrossRef]

57. Duan, L.; Ma, Y.; Chi, J.; Wang, X.; Wesely, A.J.; Chen, X. The regulatory role of immunosupressants on immune abnormalities in acute pancreatitis. Biomed. Rep. 2014, 2, 193-198. [PubMed]

58. Watanabe, T.; Kudo, M.; Strober, W. Immunopathogenesis of pancreatitis. Mucosal Immunol. 2017, 10, $283-298$. [CrossRef] [PubMed]

59. Jaworek, J.; Konturek, S.J. Hormonal protection in acute pancreatitis by ghrelin, leptin and melatonin. World J. Gastroenterol. 2014, 20, 16902-16912. [CrossRef] [PubMed]

60. Szabolcs, A.; Reiter, R.J.; Letoha, T.; Hegy, P.; Papai, G.; Varga, I.; Jarmay, K.; Kaszaki, J.; Sari, R.; Rakonczay, Z., Jr.; et al. Effect of melatonin on the severity of L-arginine-induced experimental pancreatitis in rats. World J. Gastroenterol. 2006, 12, 251-258. [CrossRef] [PubMed]

61. Jaworek, J. Ghrelin and melatonin in the regulation of pancreatic exocrine secretion and maintaining of integrity. J. Physiol. Pharmacol. 2006, 57, 83-96. [PubMed]

62. Qi, W.; Tan, R.X.; Reiter, R.J. Melatonin reduces lipid peroxidation and tissue edema in caerulein-induced acute pancreatitis in the rats. Dig. Dis. Sci. 1999, 44, 2257-2262. [CrossRef] [PubMed]

63. Jaworek, J.; Konturek, S.J.; Leja-Szpak, A. Role of endogenous melatonin and its $\mathrm{MT}_{2}$ receptor in the modulation of caerulein-induced pancreatitis in the rat. J. Physiol. Pharmacol. 2002, 53, 791-804. [PubMed]

64. Esrefoglu, M.; Gul, M.; Ates, B.; Selimoglu, M.A. Ultrastructural clues for the protective effect of melatonin against oxidative damage in cerulein-induced pancreatitis. J. Pineal Res. 2006, 40, 92-97. [CrossRef] [PubMed]

65. Carrasco, C.; Marchena, A.M.; Holquin-Arevalo, M.S.; Martin-Partido, G.; Rodriquez, A.B.; Paredes, S.D.; Pariente, J.A. Anti-inflammatory effect of melatonin in a rat model of caerulein-induced acute pancreatitis. Cell Biochem. Funct. 2013, 31, 585-590. [CrossRef] [PubMed]

66. Chen, H.M.; Chen, J.C.; Ng, C.J.; Chiu, D.F.; Chen, M.F. Melatonin reduces pancreatic prostaglandins production and protects against caerulein-induced pancreatitis. J. Pineal Res. 2006, 40, 34-39. [CrossRef] [PubMed]

67. Jaworek, J.; Konturek, S.J.; Tomaszewska, R.; Leja-Szpak, A.; Bonior, J.; Nawrot, K.; Palonek, M.; Stachura, J.; Pawlik, W. The circadian rhythm of melatonin modulates the severity of caerulein-induced pancreatitis in the rat. J. Pineal Res. 2004, 37, 161-170. [CrossRef] [PubMed]

68. Col, C.; Dinler, K.; Hasdemir, A.O.; Bugdayci, G. The effect of intraperitoneal injection of melatonin on serum amylase levels in acute pancreatitis. JOP 2009, 10, 306-309. [PubMed]

69. Baykal, A.; Iskit, A.B.; Hamaloglou, E.; Oguz, M.; Hascelik, G.; Sayek, Y. Melatonin modulates mesenteric blood flow and TNF alpha concentrations after lipopolysaccharide challenge. Eur. J. Surg. 2000, 166, $722-727$. [PubMed]

70. Sadek, A.S.; Khattab, R.S. The protective role of melatonin on L-arginine-induced acute pancreatitis. Folia Morphol. 2017, 76, 66-73. [CrossRef] [PubMed]

71. Huai, J.P.; Shao, Y.; Sun, X.C.; Jin, Y.; Wu, J.S.; Huang, Z.M. Melatonin ameliorates necrotizing pancreatitis by the regulation of cytosolic $\mathrm{Ca}+2$ homeostasis. Pancreatology 2012, 12, 257-263. [CrossRef] [PubMed]

72. Chen, Y.; Zhang, J.; Zhao, Q.; Chen, Q.W.; Sun, Y.; Jin, Y.; Wu, J. Melatonin induces anti-inflammatory effects to play a protective role via endoplasmatic reticulum stress in acute pancreatitis. Cell. Physiol. Biochem. 2016, 40, 1094-1104. [CrossRef] [PubMed]

73. Gulben, K.; Ozdemir, H.; Berberoglu, U.; Mersin, H.; Yrkin, F.; Cahyr, E.; Aksaray, S. Melatonin modulates the severity of taurocholate-induced acute pancreatitis. Dig. Dis. Sci. 2010, 55, 941-946. [CrossRef] [PubMed]

74. Bonior, J.; Jaworek, J.; Konturek, S.J.; Pawlik, W.W. Increase of heat shock protein gene expression by melatonin in AR42J cells. J. Physiol. Pharmacol. 2005, 56, 471-481. [PubMed]

75. Sun, X.; Shao, Y.; Jin, Y.; Huai, J.; Zhou, Q.; Huang, Z.; Wu, J. Melatonin reduces bacterial translocation by preventing damage to the intestinal mucosa in an experimental severe pancreatitis rat model. Exp. Ther. Med. 2013, 6, 1343-1349. [PubMed]

76. Chou, T.Y.; Reiter, R.J.; Chen, K.H.; Leu, F.J.; Wang, D.; Yeh, D.Y. Pulmonary function changes in rats with taurocholate-induced pancreatitis are attenuated by pretreatment with melatonin. J. Pineal Res. 2014, 56, 196-203. [CrossRef] [PubMed] 
77. Sidhu, S.; Pandhi, P.; Malhortra, S.; Vaiphei, K.; Khanduya, K.L. Melatonin treatment is beneficial in pancreatic repair process after experimental acute pancreatitis. Eur. J. Pharmacol. 2010, 628, 282-289. [CrossRef] [PubMed]

78. Jaworek, J.; Szklarczyk, J.; Bonior, J.; Kot, M.; Goralska, M.; Pierzchalski, P.; Reiter, R.J.; Czech, U.; Tomaszewska, R. Melatonin metabolite, $N^{1}$-acetyl- $N^{1}$-formyl-5nmethoxykynuramine (AFMK), attenuates acute pancreatitis in the rat: In vivo and in vitro studies. J. Physiol. Pharmacol. 2016, 676, 411-421.

79. Chen, G.Y.; Dai, R.W.; Luo, H.; Chen, T.; Lin, N.; Wang, T.; Luo, G.D.; Tang, L.J. Effect of percutaneous catheter drainage on pancreatic injury in rats with severe acute pancreatitis induced by sodium taurocholate. Pancreatology 2015, 15, 71-77. [CrossRef] [PubMed]

80. Booth, D.M.; Murphy, J.A.; Mukherjee, R.; Awais, M.; Neoptolemos, J.P.; Gerasimenko, O.V.; Tepikin, A.V.; Petersen, O.H.; Sutton, R.; Criddle, D.N. Reactive oxygen species induced by bile acid induce apoptosis and protect against necrosis in pancreatic acinar cells. Gastroenterology 2011, 140, 2116-2125. [CrossRef] [PubMed]

81. Laothong, U.; Hiraku, Y.; Oikawa, S.; Intuyod, K.; Murata, M.; Pinlaor, S. Melatonin induces apoptosis in cholangiocarcinoma cell lines by activating the reactive oxygen species-mediated mitochondrial pathway. Oncol. Rep. 2015, 33, 1443-1449. [CrossRef] [PubMed]

82. Xu, C.; Wu, A.; Zhu, H.; Fang, H.; Xu, L.; Ye, J.; Shen, J. Melatonin is involved in the apoptosis and necrosis of pancreatic cancer cell line via modulating of Bcl-2/Bax balance. Biomed. Pharmacother. 2013, 67, 133-139. [CrossRef] [PubMed]

83. Wei, J.Y.; Li, M.W.; Zhou, L.L.; Lu, Q.N.; He, W. Melatonin induced apoptosis of colorectal cancer cells through HDAC4 nuclear import mediated by CaMKII inactivation. J. Pineal Res. 2015, 58, 429-438. [CrossRef] [PubMed]

84. Jaworek, J.; Zwirska-Korczala, K.; Szklarczyk, J.; Nawrot-Porąbka, K.; Leja-Szpak, A.; Jaworek, A.K.; Tomaszewska, R. Pinealectomy aggravates acute pancreatitis in the rat. Pharmacol. Rev. 2010, 62, 864-873. [CrossRef]

85. Belayev, O.; Herzog, T.; Munding, J.; Bolik, B.; Vosschulte, A.; Uhl, W.; Muller, C.A. Protective role of endogenous melatonin in the early course of human acute pancreatitis. J. Pineal Res. 2011, 50, 71-77. [CrossRef] [PubMed]

86. Jin, Y.; Lin, C.J.; Dong, L.M.; Chen, M.J.; Zhou, Q.; Wu, J.S. Clinical significance of melatonin concentrations in predicting the severity of acute pancreatitis. World J. Gastroenterol. 2013, 19, 4066-4071. [CrossRef] [PubMed]

87. Leja-Szpak, A.; Jaworek, J.; Szklarczyk, J.; Konturek, S.J.; Pawlik, W.W. Melatonin stimulates HSP27 phosphorylation in human pancreatic carcinoma cells (PANC-1). J. Physiol. Pharmacol. 2007, 58, 177-188. [PubMed]

88. Jaworek, J.; Leja-Szpak, A. Melatonin influences pancreatic cancerogenesis. Histol. Histopathol. 2014, 29, 423-431. [PubMed]

89. Li, W.; Wu, J.; Li, Z.; Zhou, Z.; Zheng, C.; Lin, L.; Tan, B.; Huang, M.; Fan, M. Melatonin induces cell apoptosis in Mia PaCa-2 cells via the suppression of nuclear factor- $\mathrm{KB}$ and activation of ERK and JNK: A novel therapeutic implication for pancreatic cancer. Oncol. Rep. 2016, 36, 2861-2867. [CrossRef] [PubMed]

90. Cucina, A.; Proietti, S.; D'Anselmi, F.; Coluccia, P.; Dinicola, S.; Frati, L.; Bizzarri, M. Evidence for a biphasic apoptotic pathway induced by melatonin in MCF-7 breast cancer cells. J. Pineal Res. 2009, 46, 172-180. [CrossRef] [PubMed]

91. Fan, C.; Pan, Y.; Yang, Y.; Di, S.; Jiang, S.; Ma, Z.; Li, T.; Zhang, Z.; Li, W.; Li, X.; et al. HDAC1 inhibition by melatonin leads to suppression of lung adenocarcinoma cells via induction of oxidative stress and activation of apoptotic pathways. J. Pineal Res. 2015, 59, 321-333. [CrossRef] [PubMed]

92. Hong, Y.; Won, J.; Lee, Y.; Lee, S.; Park, K.; Chang, K.T.; Hong, Y. Melatonin treatment induces interplay of apoptosis, autophagy, and senescence in human colorectal cancer cells. J. Pineal Res. 2014, 56, 264-274. [CrossRef] [PubMed]

93. Kim, T.K.; Lin, Z.; Tidwell, W.J.; Li, W.; Slominski, A.T. Melatonin and its metabolites accumulate in the human epidermis in vivo and inhibit proliferation and tyrosinase activity in epidermal melanocytes in vitro. Mol. Cell. Endocrinol. 2015, 404, 1-8. [CrossRef] [PubMed]

94. Leja-Szpak, A.; Pierzchalski, P.; Goralska, M.; Nawrot-Porabka, K.; Bonior, J.; Link-Lenczowski, P.; Jastrzebska, M.; Jaworek, J. Kynuramines induce overexpression of heat shock proteins in pancreatic cancer cells via 5-hydroxytryptamine and $\mathrm{MT}_{1} / \mathrm{MT}_{2}$ receptors. J. Physiol. Pharmacol. 2015, 66, 711-718. [PubMed] 
95. Rozov, S.V.; Filatova, E.V.; Orlov, A.A.; Volkova, A.V.; Zhloba, A.R.; Blashko, E.L.; Pozdeyev, N.V. $N^{1}$-acetyl-N $N^{2}$-formyl-5-methoxykynuramine is a product of melatonin oxidation in rats. J. Pineal Res. 2003, 35, 245-250. [CrossRef] [PubMed]

96. Onuki, J.; Almeida, E.A.; Medeiros, M.H.; di Mascio, P. Inhibition of 5-aminolevulinic acid-induced DNA damage by melatonin, $N^{1}$-acetyl- $N^{2}$-formyl-5-methoxykynuramine, quercetin or resveratrol. J. Pineal Res. 2005, 38, 107-115. [CrossRef] [PubMed]

97. Boutin, J.A.; Marcheteau, E.; Hennig, P.; Moulharat, N.; Berger, S.; Delagrange, P.; Bouchet, J.P.; Ferry, G. MT3/QR2 melatonin binding site does not use melatonin as a substrate or a co-substrate. J. Pineal Res. 2008, 45, 524-531. [CrossRef] [PubMed]

98. Budu, A.; Peres, R.; Bueno, V.B.; Catalani, L.H.; Garcia, C.R. $N^{1}$-acetyl- $N^{2}$-formyl-5-methoxykynuramine modulates the cell cycle of malaria parasites. J. Pineal Res. 2007, 42, 261-266. [CrossRef] [PubMed]

99. Dragicevic, N.; Copes, N.; O’Neal-Moffitt, G.; Jin, J.; Buzzeo, R.; Mamcarz, M.; Tan, J.; Cao, C.; Olcese, J.M.; Arendash, G.W.; et al. Melatonin treatment restores mitochondrial function in Alzheimer's mice: A mitochondrial protective role of melatonin membrane receptor signaling. J. Pineal Res. 2011, 51, 75-86. [CrossRef] [PubMed]

100. Ju, HQ.; Li, H.; Tian, T.; Lu, Y.X.; Bai, L.; Chen, L.Z.; Sheng, H.; Mo, H.Y.; Zeng, J.B.; Deng, W.; et al. Melatonin overcomes gemcitabine resistance in pancreatic ductal adenocarcinoma by abrogating nuclear factor- $\kappa$ B activation. J. Pineal Res. 2016, 60, 27-38. [CrossRef] [PubMed]

101. Uguz, A.C.; Cig, B.; Espino, J.; Bejarano, I.; Naziroglu, M.; Rodríguez, A.B.; Pariente, J.A. Melatonin potentiates chemotherapy-induced cytotoxicity and apoptosis in rat pancreatic tumor cells. J. Pineal Res. 2012, 53, 91-98. [CrossRef] [PubMed]

(C) 2017 by the authors. Licensee MDPI, Basel, Switzerland. This article is an open access article distributed under the terms and conditions of the Creative Commons Attribution (CC BY) license (http:/ / creativecommons.org/licenses/by/4.0/). 